UDC $612.017 .12+591.441+571.27$

doi: https://doi.org/10.15407/ubj91.01.030

\title{
DIFFERENT MICE INBRED STRAINS HUMORAL IMMUNE RESPONSE AGAINST HUMAN PROSTATE-SPECIFIC ANTIGEN
}

\author{
O. Yu. GALKIN ${ }^{1,2 \varpi}$, A. G. KOMAR ${ }^{3}$, O. B. BESARAB \\ ${ }^{1}$ National Technical University of Ukraine "Igor Sikorsky Kyiv Polytechnic Institute”; \\ e-mail: alexfbt@gmail.com; \\ ${ }^{2}$ Propharma Plant Ltd., Kyiv; \\ ${ }^{3}$ Ukrainian Medical Center of Certification of Ministry of Health of Ukraine, Kyiv
}

Received: 21 August 2018; Accepted: 13 December 2018

The aim of the study was an investigation of humoral immune response to prostate-specific antigen (PSA) of different mice inbred strains for further development of recommendations for appropriate immunization schemes for monoclonal antibodies (McAbs) obtaining. The study was conducted using: Balb/c and NZB mice; PSA from human sperm (as immunogen). In case of booster immunization immunogen was previously diluted to the desired concentration (10 or $30 \mu \mathrm{g}$ per $100 \mu \mathrm{l})$ in saline, and injected in the tail vein or intraperitoneally. In case of other immunizations, we prepared emulsion solution of immunogen with adjuvant to final concentration of 10 or $30 \mu \mathrm{g}$ per $100 \mu \mathrm{l}$ : PSA was dissolved in saline, the same volume of adjuvant was added, and mixture was thoroughly mixed to form a stable emulsion. When subcutaneous administration, total dose of $100 \mu \mathrm{l}$ was divided into two equal parts and injected in the hind paw of mice. Intraperitoneal immunization was performed by single administration of $100 \mu \mathrm{l}$ of emulsion. The level of specific antibodies was determined by titration of blood sera from animals in indirect ELISA. Series of experiments were conducted to determine the level of humoral response of mice of different inbred strains (Balb/c and NZB) for multi-stage immunization with different duration with different amounts of PSA (10 and $30 \mu \mathrm{g}$ ), with different immunoglobulin administration (intraperitoneal and subcutaneously), and with different adjuvants (Freund's complete and incomplete adjuvants, FCA/FIA). Final booster immunization at a dose of $30 \mu \mathrm{g}$ was performed either in the same manner as the previous administration of the immunogen, or intravenously in the physiological saline solution. Dependencies of the humoral immune response of Balb/c and NZB mice against PSA on the route of administration of immunogen, the dose and duration of immunization were established. It was shown that intraperitoneal administration provided formation of higher titers of specific antibodies in case of both mice strains. Balb/c mice lines more rapidly responded to PSA, than an NZB mice (for all investigated schemes immunization). It was shown that the most effective immunization scheme was three times intraperitoneal administration with $10 \mu \mathrm{g}$ of PSA for 8 weeks (the first immunization with FCA, and the rest - with FIA) and booster immunogen intravenous administration in saline solution.

Key words: immunization schemes, prostate-specific antigen, Balb/c and NZB mice.

$\mathrm{P}$ rostate-specific antigen (PSA), also known as gamma-seminoprotein or kallikrein 3 (KLK3), is a glycoprotein enzyme with a molecular weight of $34 \mathrm{kDa}$, containing $237 \mathrm{ami}-$ no acid residues, is related to serine proteinases (EC 3.4.21.77). PSA is encoded by the KLK3 gene, which is localized on the $19^{\text {th }}$ chromosome (19q13) in humans. PSA in the sperm splits semenogelins present in the seminal coagulum. The overall level of PSA is increased in serum in patients with prostatitis, benign hyperplasia and prostate cancer (PC). PSA is a biomarker for PC risk assessment. Serum protease inhibitors such as $\alpha 1$-antichymotrypsin $\left(\alpha_{1}-\right.$ ACT), $\alpha_{2}$-macroglobulin $\left(\alpha_{2}-\mathrm{MG}\right)$, and other acute-

(C) 2019 Galkin O. Yu. et al. This is an open-access article distributed under the terms of the Creative Commons Attribution License, which permits unrestricted use, distribution, and reproduction in any medium, provided the original author and source are credited. 
protein proteins form irreversible complexes with circulating PSA and inhibit its proteolytic activity [1-7].

PSA is used in the development of immunological tests and biosensors. Research and development in the field of immune biotechnology sometimes require bioreagents - antibodies specific to PSA $[4,6]$. From the biotechnological position, the starting point for any serological method is the immune response. And hence one of the most important fundamental grounds of the creation of serological diagnostic kits is the understanding of the regularity and features of the immune response against the certain antigen [8-11]. The most appropriate is specific monoclonal antibodies (McAbs), as they, unlike polyclonal antibodies are characterized by exceptional specificity, homogeneity and possibility of obtaining in unlimited quantities. Constant identity of McAbs isotype and idiotype from batch to batch ensures their constant appropriate quality and hence the reproducibility of analytical methods [12]. One of the important elements of the hybridoma technology is the use of effective immunization schemes that would provide tremendous specificity repertoire of McAbs with high affinity and activity in different immunoassay methods [13]. In our previous work, good results were shown in expanding the epitope repertoire of McAbs using different mice inbred strains, in particular Balb/c and NZB mice [14].

The aim of the study has been investigation of humoral immune response to prostate-specific antigen of different mice inbred strains for further development of recommendations for appropriate immunization schedule for monoclonal antibodies obtaining.

\section{Materials and Methods}

Animals. Balb/c and NZB mice were used for immunization: females aged 6-8 months, 20-22 g weight. The animals were kept in cages in natural light, temperature $20-22{ }^{\circ} \mathrm{C}$; access to food and water was free. In total, 32 mice were used for immunization. Studies on animals were carried out in compliance with bioethical norms [15].

Immunogen. Prostate-specific antigen from human sperm (Sigma, USA) used as immunogen was buffered aqueous solution with $99 \%$ purity (by electrophoresis); protein concentration was $0.5-0.6 \mathrm{mg} /$ $\mathrm{ml}$.

Immunization protocols. In case of booster (final) immunization immunogen was previously di- luted to the desired concentration (10 or $30 \mu \mathrm{g}$ per $100 \mu 1)$ in saline and injected in the tail vein or intraperitoneal. In case of other immunizations, emulsion solution of immunogen has been prepared with adjuvant (Freund's complete or incomplete adjuvant, see Fig. 1) to final concentration of 10 or $30 \mu \mathrm{g}$ per $100 \mu 1$ of emulsion solution: PSA was dissolved in saline, the same volume of adjuvant was added, and mixture was thoroughly mixed to form a stable emulsion. When subcutaneous administration total dose of 10 or $30 \mu \mathrm{g}$ was divided into two equal parts and was injected in the hind paws of mice. Intraperitoneal immunization was performed by single administration of antigen containing emulsion. Immunogen solution (emulsion) was prepared immediately before immunization. The choice of doses of antigen was determined by literature data [17, 18], as well as our previous experience [14].

Periodate method of synthesis of peroxidase polyclonal antibodies (PcAbs) conjugates. Conjugation of goats' PcAbs against mouse immunoglobulins with horseradish peroxidase (HRP) (alkaline form) (Sigma, USA) was carried out at the mass ratio antibodies : enzymes equal $2: 1$ by the method of periodate oxidation by Tissen [19] with own modifications [20]. HRP was dissolved in $0.1 \mathrm{M}$ carbonatebicarbonate buffer solution (CBBS), $\mathrm{pH} 8.0$, up to a concentration of $15 \mathrm{mg} / \mathrm{ml}$, and then riveted volume of water solution of sodium periodate $(14 \mathrm{mM})$ was added. For HRP oxidation reaction mixture was incubated for 2 hours at room temperature. The obtained solution of oxidized HRP was mixed with a solution of dialyzed antibodies (against 0.1 M CBBS, $\mathrm{pH}$ 9.2). The mixture was cyclically passed through a $0.45 \mu \mathrm{m}$ filter for $10 \mathrm{~min}$ at room temperature (filter material was a mixture of biologically inert acetate and cellulose nitrate, Millipore, USA). The conjugate solution was eluted from the column and a 1/20 volume portion of aqueous $\mathrm{NaBH} 4$ solution $(5 \mathrm{mg} /$ $\mathrm{ml}$ ) was added. To stop the reaction, the mixture was cooled to $4{ }^{\circ} \mathrm{C}$, and then another $3 / 20$ parts of $\mathrm{NaBH} 4$ solution was added, incubated for $60 \mathrm{~min}$ at room temperature. The resulting solution of peroxidase conjugate PcAbs was transferred to $0.02 \mathrm{M}$ phosphate buffer solution containing $0.15 \mathrm{M} \mathrm{NaCl}$ (PBS), $\mathrm{pH}$ 7.2, by dialysis.

Enzyme-linked immunosorbent assay (ELISA). PSA in $0.02 \mathrm{M}$ carbonate buffer ( $\mathrm{pH}$ 9.5) was immobilized on the surface of the polyester plates with high sorption capacity (Suzhou Conrem Biomedical Technology Co., China) overnight at $4{ }^{\circ} \mathrm{C}(2 \mu \mathrm{g} /$ 
well). After washing the plates by phosphate saline buffer with $0.05 \%$ Tween-20, pH 7.2-7.4 (FSBT) titration of mice blood sera (100 ml/well) was conducted. After incubation for $1 \mathrm{~h}$ at $37^{\circ} \mathrm{C}$ and washing with FSBT. PSA-specific antibodies detection was carried out with peroxidase conjugates of goats' anti-mouse PcAbs in FSBT ( $100 \mathrm{ml} /$ well). Plates were incubated $1 \mathrm{~h}$ at $37{ }^{\circ} \mathrm{C}$, washed with FSBT. $0.003 \%$ hydrogen peroxide in $0.15 \mathrm{M}$ citrate buffer ( $\mathrm{pH}$ 5.0) was used as substrate, and 3,3',5,5'-tetramethylbenzidine was a chromogen. The reaction was stopped by $2 \mathrm{M}$ sulphuric acid. The optical density values were read at wave lengths $450 / 620 \mathrm{~nm}$ by spectrophotometer.

\section{Results and Discussion}

Rationale immunization schemes. A prerequisite for an in-depth study of the effectiveness of various immunization schemes for the production of antibodies to PSA was an analysis of literature data on the obtaining and characterization of antiPSA McAbs [16-18], as well as comparison of these data with our own experience of obtaining McAbs of other specificity $[14,12]$. The immunization schemes described in the literature vary in duration (from 1 to 10 months), the number of immunizations, the dose of the immunogen per animal per each injection (from 10 to $30 \mu \mathrm{g}$ for primary immunization, and from 10 to $150 \mu \mathrm{g}$ for the final booster immunization). Not all of described immunization schemes included a final booster dose with a large amount of the immunogen. The common features of all described immunization schemes were the use of Balb/c mice; in all cases, Freund's complete adjuvant (FCA) was used, and injections were performed intraperitoneally.

Our previous experience in obtaining of McAbs to human immunoglobulins of different classes demonstrated the efficacy of 7 days of Balb/c mice immunization in the hind paws of mice (two injections has been done with FCA, and final injection without adjuvant) with subsequent hybridization of lymphocytes of regional lymph nodes. The choice of such a scheme of immunization was due to the fact that human immunoglobulins are a strong immunogen for mice, as well as lead to the development of severe hypersensitivity reactions [21]. This immunization scheme allowed us to receive high yields of positive hybrids that synthesized high affinity (affinity constant up to $10^{10} \mathrm{M}^{-1}$ ) and specific McAbs [12].

In the case of immunization with the major outer membrane protein Chlamydia trachomatis
(MOMP), we used the scheme described above, however, with the intravenous booster immunization 3-4 months after the first injection, followed by hybridization of splenocytes of the spleen. The results of this hybridization can also be estimated as highly effective. The immunization of Balb/c and NZB mice with horseradish peroxidase (HRP) has a certain number of features. Using the immunization scheme described above (when receiving anti-MOMP McAbs), hybridization resulted in significantly less positive clones in the hybrid: after the initial testing, only a quarter of the wells of the culture plates showed positive clones. McAbs, synthesized by these hybridomas, were characterized by a rather low titre (less than 1:5000) and an affinity constant (less than $10^{8} \mathrm{M}^{-1}$ ). HRP as an immunogen was quite toxic: there was an inflammatory reaction in the paws of experimental animals, up to the partial necroticisation of the pads of the hind legs. We used the above experience of McAbs obtaining for the following reasons. Firstly, it should be noted that both humans and mice have proteins with similar function and structure, in this case we are talking about PSA and immunoglobulins. Secondly, PSA and horseradish peroxidase are enzymes that can cause some features of immunization with these proteins. Third, proteins with the close molecular weights, such as PSA and MOMP, may also have similar properties as immunogens.

In some studies [22, 23] were described the immunization scheme for so-called "weak" immunogens. In our opinion, experimental works [2426] using mice NZB, which are characterized by a high level of B-cell immune response, are of special interest. However, our studies [14] have shown the ability to significantly expand the specificity of obtained McAbs when NZB mice had been used; and it's important in applied research in the field of immunobiotechnology.

The above facts led us to a series of experiments to determine the level of humoral response of mice of different inbred strains (Balb/c and NZB) for multi-stage immunization with different duration with different amounts of PSA (10 and $30 \mu \mathrm{g}$ ), with different immunoglobulin administration (intraperitoneal and subcutaneously). Final booster immunization at a dose of $30 \mu \mathrm{g}$ was performed either in the same manner as the previous administration of the immunogen, or intravenously in the physiological saline solution. The general scheme of the experiment is presented in Fig. 1. 
Comparison of different immunization schemes of Balb/c and NZB mice by PSA. To assess the level of humoral immune response to PSA titration of blood serum of animals in an indirect ELISA was used. The evaluation of the data on the dynamics of the humoral immune response of mice of different lines with different immunization schemes are presented in fig. 2. Serial immunization of mice was expected to increase the level of humoral immune response to PSA. At the same time, intraperitoneal immunizations provided a more intensive growth of the titre of specific serum antibodies for both lines of mice compared with subcutaneously administration (Fig. 2, $A$ and $B$, as compared with Fig. 2, $C$ and $D$, respectively). This difference is especially noticeable when testing serums at the points of experiment No. 3-5. It should also be noted that during the final intravenous booster immunization, a more pronounced humoral immune response was observed for both lines of mice and both final immunization points. Such data indicate that for PSA as immunogen intravenous booster immunization is more effective. Such data are in good agreement with the results of our previous works, which were mentioned earlier [12, 14].
Interesting results were obtained at determination of the dependence of the level of humoral immune response from immunogen dose. When using the highest dose of PSA $(30 \mu \mathrm{g})$ in the case of subcutaneous administration, there was no apparent tendency to increase the titre of specific antibodies compared to lower immunogenic doses: administration of a dose of $30 \mu \mathrm{g}$ PSA often provided the formation of the same titre of antibodies as for dose $10 \mu \mathrm{g}$ (this is especially noticeable at the experimental points No. 3-5). In the case of intraperitoneal injections, such regularity when administered the highest dose of the immunogen was not observed. Such results can be explained by the inflammatory and degenerative processes in the hind limb of the mice when the immunogen is injected, which increased during the experiment. Obviously, the effectiveness of immunization depends on the efficiency of immunogen delivery into immunocompetent cells. With increasing degenerative processes in the hind legs of animals, obviously, the delivery of PSA to spleen cells through the bloodstream deteriorated.

It should also be noted that there was no significant difference in levels of humoral immune response for NZB and Balb/c mice, although the latter

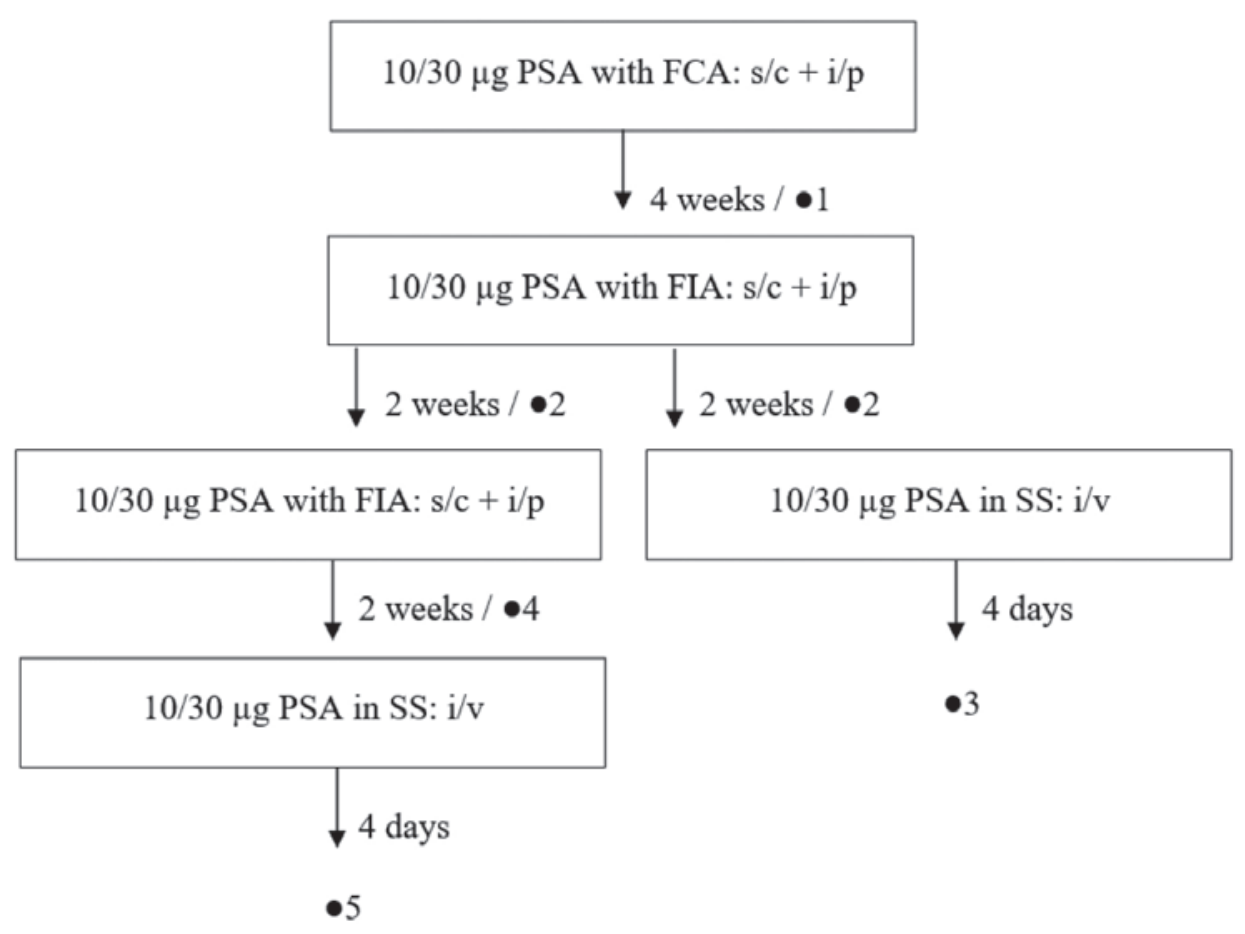

Fig. 1. Schemes for Balb/c and NZB mice immunization with PSA. FCA - Freund's complete adjuvant; FIAFreund's incomplete adjuvant; $S S$ - saline solution; i/p - intraperitoneal, s/c - subcutaneous, i/v - intravenous administration; $\bullet$ - points for blood sampling for the study of specific antibodies titer 

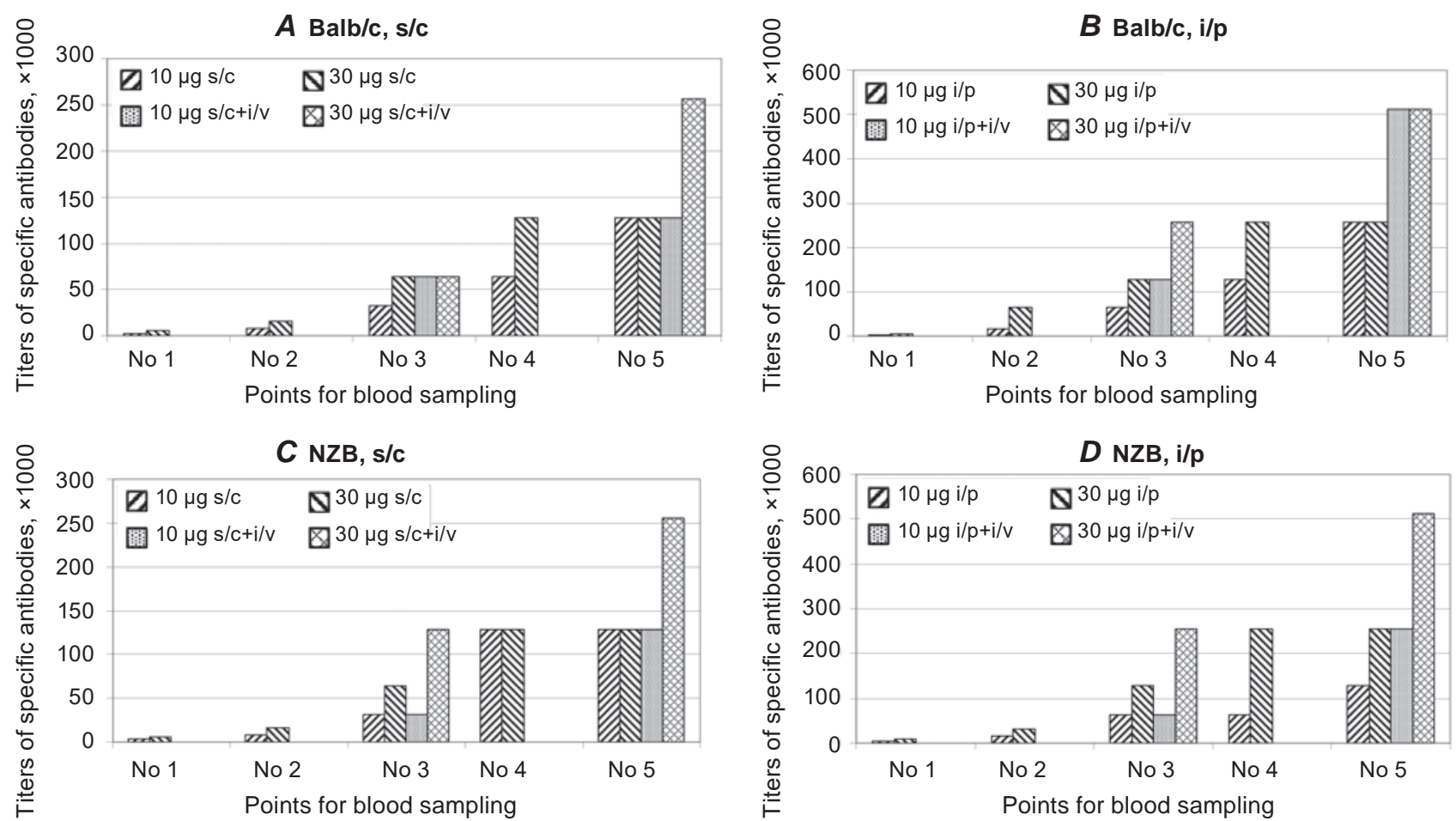

Fig. 2. Results of determination of specific antibodies in the serum of mice at different immunization schemes

in some cases showed somewhat higher antibody titres.

Thus, the most active immune response to PSA was recorded in Balb/c mice. In this case, the dose of the immunogen $10 \mu \mathrm{g}$ already provided the highest level of titre of specific antibodies (Fig. 2, B). In our experiments, we injected a booster dose of an immunogen after two (6 weeks) and three ( 8 weeks) successive immunizations (control points No. 3 and 5). It has been shown that the 8-week immunization scheme provides for the formation of significantly higher titres of antibodies in the serum of animal blood. This immunization scheme can by recommended for obtaining of McAbs to PSA.

It is important to compare our results with the data of other authors who have been working with anti-PSA McAbs. We propose to review in more detail the results of three studies on the characteristics of McAbs to PSA [16-18]. The closest immunization scheme recommended to us is that described by Leinonen et al. [18]. In this work, all immunizations of the Balb/c mice, including the final booster immunization, were performed with FCA using a range of doses from 10 to $30 \mu \mathrm{g}$ per animal for each of the immunizations. The final administration of the immunogen was carried out at different doses (10,
100 and $150 \mu \mathrm{g})$. The total duration of immunization was 4 weeks. Unfortunately, the authors do not indicate which version of the immunization was used to obtain certain McAbs. The resulting set of 6 McAbs was characterized in the context of their epitope specificity with the use of peptic libraries, which allowed detecting both linear and conformational epitopes. In general, obtained McAbs were directed to the three epitop regions of the PSA molecule. However, among the characteristics of McAbs' set, unfortunately, their affinity constants are absent; but it is important parameter both for assessing the effectiveness of the used immunization scheme and for estimating the prospects for McAbs' using in immunological approaches and biotechnology. Michel et al. [16] reported characteristics of the 7 McAbs against PSA (specific to both free and complexed with $\alpha 1-\mathrm{ACT}$ ) that were obtained by the following immunization scheme. The Balb/c mice were used; all injections were performed intraperitoneally with FCA at a dose of $15 \mu \mathrm{g}$ of PSA per animal. The immunization scheme included 5 injections, in 2 weeks (total duration was 10 weeks). The epitope characteristic of the obtained McAbs included the use of a phage display and its comparative analysis (on the ability to compete with each other). McAbs, obtained 
by this immunization scheme, were characterized by different levels of the affinity constant: from $10^{7}$ to $10^{9} \mathrm{M}^{-1}$.

Nurmikko et al. [17] have characterized seven McAbs (one of them was specific to free PSA, five was interacted with PSA- $\alpha 1-A C T$ complex, and another one showed cross-activity to the proteins of related families). The obtained McAbs were characterized by rather high levels of the affinity constant $\left(10^{9}-10^{10} \mathrm{M}^{-1}\right)$, but the data presented do not allow to determine which immunization scheme provided this result. The authors attested only such details: the Balb/c mice were used, immunization was carried out intraperitoneally with FCA (every 3-4 weeks), the total duration of the schemes varied from 2 to 10 months. Based on the above analysis of the literature data, our received results regarding the choice of doses, way and method of administration of the immunogen, the duration of immunization for mice of various inbred lines are important both from the fundamental and applied points of view.

Thus, dependencies of the humoral immune response of Balb/c and NZB mice against PSA on the route of administration of immunogen, the dose and duration of immunization were established. It was shown that intraperitoneal administration provided formation of higher titers of specific antibodies in case of both mice strains. Balb/c mice lines more rapidly responded to PSA, than an NZB mice (for all investigated schemes immunization). It was shown that the most effective immunization scheme was three times intraperitoneal administration with $10 \mu \mathrm{g}$ of PSA for 8 weeks (the first immunization with FCA, and the rest - with FIA) and booster immunogen intravenous administration in saline solution.

Conflict of interest. Authors have completed the Unified Conflicts of Interest form at http:// ukrbiochemjournal.org/wp-content/uploads/2018/12/ coi_disclosure.pdf and declare no conflict of interest.

\section{ГУМОРАЛЬНА ІМУННА ВІДПОВІДЬ МИШЕЙ РІЗНИХ ІНБРЕДНИХ ЛІНІЙ НА ПРОСТАТИЧНИЙ СПЕЦИФІЧНИЙ АНТИГЕН ЛЮДИНИ}

\author{
О. Ю. Галкін ${ }^{1,2 凶}$, А. Г. Комар \\ О. Б. Бесараб
}

\author{
${ }^{1}$ Національний технічний університет \\ України «Київський політехнічний \\ інститут імені Ігоря Сікорського»; \\ e-mail: alexfbt@gmail.com; \\ ${ }^{2}$ TOB «Профарма Плант», Київ, Україна; \\ ${ }^{3}$ Український медичний центр \\ сертифікації МОЗ України, Київ
}

Метою дослідження було вивчення гуморальної імунної відповіді на простатичний специфічний антиген (ПСА) для різних типів інбредних ліній мишей 3 подальшим формуванням рекомендацій щодо відповідних схем імунізації для одержання моноклональних антитіл (МкАт). Дослідження проводили 3 використанням мишей ліній Balb/c та NZB; ПСА із сперми людини (як імуноген). У разі бустер-імунізацій імуноген попередньо розводили до потрібної концентрації (10 або 30 мкг на 100 мкл) у фізіологічному розчині та вводили у хвостову вену або внутрішньочеревно. За іншої імунізації готували емульсійний розчин імуногену з ад’ювантом до кінцевої концентрації 10 або 30 мкг на 100 мкл: ПСА розчиняли у фізіологічному розчині, додавали такий самий об'єм ад’юванта, і суміш ретельно змішували, щоб утворити стабільну емульсію. Загальну дозу 100 мкл поділяли на дві рівні частини і вводили підшкірно в задні лапи мишей. Імунізація проводилася шляхом одноразового в/ч введення 100 мкл емульсії. Рівень специфічних антитіл визначали титруванням сироватки крові тварин за допомогою непрямого імуноензиматичного аналізу. Проведено серію експериментів для 
визначення рівня гуморальної відповіді мишей за багатоступеневої імунізації різної тривалості 3 ПСА (10 і 30 мкг), за внутрішньочеревного введення імуногену та підшкірно 3 різними ад'ювантами (повний та неповний ад'юванти Фрейнда, ПАФ/НАФ). Остаточну бустерну імунізацію в дозі 30 мкг проводили або способом попереднього введення імуногену, або внутрішньовенно у фізіологічному розчині. Встановлено закономірності гуморальної імунної відповіді мишей на ПСА залежно від шляху введення імуногену, його дози та тривалості імунізації. Доведено, що внутрішньочеревне введення забезпечує утворення вищих титрів специфічних антитіл для обох досліджуваних ліній мишей. Миші лінії Balb/c інтенсивніше відповідають на ПСА, ніж миші лінії NZB (для всіх досліджених схем імунізації). Показано, що найефективнішою $є$ схема імунізації з трикратним внутрішньочеревним введенням 10 мкг ПСА впродовж 8 тижнів (перше введення - із ПАФ, решта - із НАФ) та бустер-введенням імуногену внутрішньовенно у фізіологічному розчині.

К л ю ч о в і с ло в а: схема імунізації, простатичний специфічний антиген, миші ліній Balb/c та NZB.

\section{References}

1. Balk SP, Ko YJ, Bubley GJ. Biology of prostatespecific antigen. J Clin Oncol. 2003; 21(2): 383391.

2. Lilja H. Biology of prostate-specific antigen. Urology. 2003; 62(5 Suppl 1): 27-33.

3. Haythorn MR, Ablin RJ. Prostate-specific antigen testing across the spectrum of prostate cancer. Biomark Med. 2011; 5(4): 515-526.

4. Ward AM, Catto JW, Hamdy FC. Prostate specific antigen: biology, biochemistry and available commercial assays. Ann Clin Biochem. 2001; 38(Pt 6): 633-651.

5. Peehl DM. Prostate specific antigen role and function. Cancer. 1995; 75(S7): 2021-2026.

6. Duskova K, Vesely S. Prostate Specific Antigen. Current clinical application and future prospects. Biomed Pap Med Fac Univ Palacky Olomouc Czech Repub. 2015; 159(1): 018-026.

7. Loeb S, Catalona WJ. Prostate-specific antigen in clinical practice. Cancer Lett. 2007; 249(1): 30-39.
8. Redchuk TA, Korotkevich NV, Kaberniuk AA, Oliinyk ES, Labyntsev AIu, Romaniuk SI, Kolibo DV, Busol VA, Komisarenko SV. Statistical analysis of distribution of antibody level against Mycobacterium bovis antigens for bovine tuberculosis diagnostics. Tsitol Genet. 2010; 44(5): 23-30. (In Russian).

9. Romaniuk SI, Kolibo DV, Kavun EM, Radavskii IuL, Tkachenko TIu, Kramarev SA, Komissarenko SV. Specificity of antibodies to diphtheria toxin subunits in children with various forms of diphtheria infections. $U k r$ Biokhim Zhurn. 2001; 73(6): 73-76. (In Russian).

10. Gavrilova ES, Bobrovnik SA, Sherriff G, Myslivets AA, Tarasov SA, Epstein OI. Novel approach to activity evaluation for release-active forms of anti-interferon-gamma antibodies based on enzyme-linked immunoassay. PLoS One. 2014; 9(5): e97017.

11. Shtapenko OV, Hevkan II, Slyvchuk YuI, Syrvatka VY, Matvienko NM. Formation and properties of polymer nanolayers to enhance cell growth in vitro. Innov Biosyst Bioeng. 2018; 2(2): 105-109.

12. Galkin OYu, Savchenko AA, Nikitina KI, Dugan OM. Obtaining and study of properties of new monoclonal antibodies against human IgE. Ukr Biokhim Zhurn. 2013; 85(5): 81-87. (In Ukrainian).

13. Galkin OY, Besarab AB, Lutsenko TN. Characteristics of enzyme-linked immunosorbent assay for detection of IgG antibodies specific to Chlamydia trachomatis heat shock protein (HSP-60). Ukr Biochem J. 2017; 89(1): 22-30.

14. Galkin AYu, Kazmirchuk VE, Bondarenko LB. Different mice inbred strains humoral immune response to horseradish peroxidase. Proc Belarus State Univ. Physiol Biochem Mol Basis Funct Biosyst. 2014; 9(1): 51-55.

15. Kozhemyakin YuM, Hromov OS, Filonenko MA, Sajfetdinova GA. Scientific and practical recommendations for the maintenance of laboratory animals and work with them. Kiev: Avicenna, 2002. 156 p. (In Ukrainian).

16. Michel S, Deléage G, Charrier JP, Passagot J, Battail-Poirot N, Sibai G, Jolivet M, JolivetReynaud C. Anti-free prostate-specific antigen monoclonal antibody epitopes defined by mimotopes and molecular modeling. Clin Chem. 1999; 45(5): 638-650. 
17. Nurmikko P, Väisänen V, Piironen T, Lindgren S, Lilja H, Pettersson K. Production and characterization of novel anti-prostate-specific antigen (PSA) monoclonal antibodies that do not detect internally cleaved Lys145-Lys146 inactive PSA. Clin Chem. 2000; 46(10): 1610-1618.

18. Leinonen J, Wu P, Stenman UH. Epitope mapping of antibodies against prostate-specific antigen with use of peptide libraries. Clin Chem. 2002; 48(12): 2208-2216.

19. Tijssen P. Practice and Theory of Enzyme Immunoassays. In: Laboratory Techniques in Biochemistry and Molecular Biology. 1985; 15: $674 \mathrm{p}$.

20. Galkin OYu, Gorshunov YuV, Besarab OB, Ivanova OM. Development and characterization of highly informative ELISA for the detection of IgG and IgA antibodies to Chlamydia trachomatis. Ukr Biochem J. 2018; 90(3): 70-83.

21. Galkin OYu, Nikolaenko IV, Spivak MYa. Monoclonal antibodies to human immunoglobulins: features of obtaining and application. Immunol Allergol. 2005; 1: 3-9. (In Ukrainian).

22. Frosch M, Görgen I, Boulnois GJ, Timmis KN, Bitter-Suermann D. NZB mouse system for production of monoclonal antibodies to weak bacterial antigens: isolation of an IgG antibody to the polysaccharide capsules of Escherichia coli K1 and group B meningococci. Proc Natl Acad Sci USA. 1985; 82(4): 1194-1198.

23. Vargas P, Cortés C, Vargas L, Rosemblatt M, Bono MR. Immunization with antigen-pulsed dendritic cells significantly improves the immune response to weak self-antigens. Immunobiology. 2006; 211(1-2): 29-36.

24. Moe GR, Dave A, Granoff DM. Epitopes recognized by a nonautoreactive murine anti-N-propionyl meningococcal group B polysaccharide monoclonal antibody. Infect Immun. 2005; 73(4): 2123-2128.

25. Nussbaum G, Anandasabapathy S, Mukherjee J, Fan M, Casadevall A, Scharff MD. Molecular and idiotypic analyses of the antibody response to Cryptococcus neoformans glucuronoxylomannan-protein conjugate vaccine in autoimmune and nonautoimmune mice. Infect Immun. 1999; 67(9): 4469-4476.

26. Zhou H, Wang Y, Wang W, Jia J, Li Y, Wang Q, $\mathrm{Wu} \mathrm{Y}$, Tang J. Generation of monoclonal antibodies against highly conserved antigens. PLoS One. 2009; 4(6): e6087. 